\title{
The Peruvian diving petrel in Peru
}

Coppelia Hays

The Peruvian diving petrel Pelecanoides garnotii is endemic to the Peruvian or Humboldt Current. Descriptions of past colonies suggest that the species was once abundant in Peru, but harvesting guano on its nesting islands and killing the birds for their meat caused a drastic decline in the population. Fishing activities and direct exploitation threaten the only two remaining breeding colonies in Peru. There are an estimated $\mathbf{4 0 0 0}$ breeding individuals left, but unless they are protected the species will continue to decline.

Of the four species of diving petrel, the Peruvian diving petrel Pelecanoides garnotii is the only one to range north into the tropics. It is commonly known as potoyunco in Peru. This species is endemic to the Peruvian or Humboldt Current, where it is normally encountered in offshore waters close to its breeding grounds. In Peru it is currently known to nest only on offshore islands, although there are reports of its nesting in colonies in the mainland (Duffy et al., 1984). Formerly it was quite numerous, but now it is in serious decline. The bulk of the surviving Peruvian diving petrel's Peruvian population is found on the islands of San Gallan and La Vieja (also referred to as Independencia island).

\section{Distribution and abundance}

The distribution of the Peruvian diving petrel extends along the west coast of South America, from Lobos de Tierra, Peru $\left(6^{\circ} \mathrm{S}\right)$ to Corral, Chile $\left(37^{\circ} \mathrm{S}\right)$. In Peru, insular colonies were previously known from Lobos de Afuera, San Gallan, La Vieja, and smaller colonies existed on Chincha Norte (Galarza, 1968) and Mazorca (Tovar, 1968). Formerly they nested abundantly on Lobos de Tierra, Macabi, Gaunape, Pescadores and Ballestas (Murphy, 1936) (Figure 1). We visited these latter islands but found that the species no longer bred there (Table 1). Even though Murphy (1925) and Coker (1919) found this 102 species to breed in great numbers at that time, they reported that the population had decreased tremendously with the extraction of the guano layer from the islands.

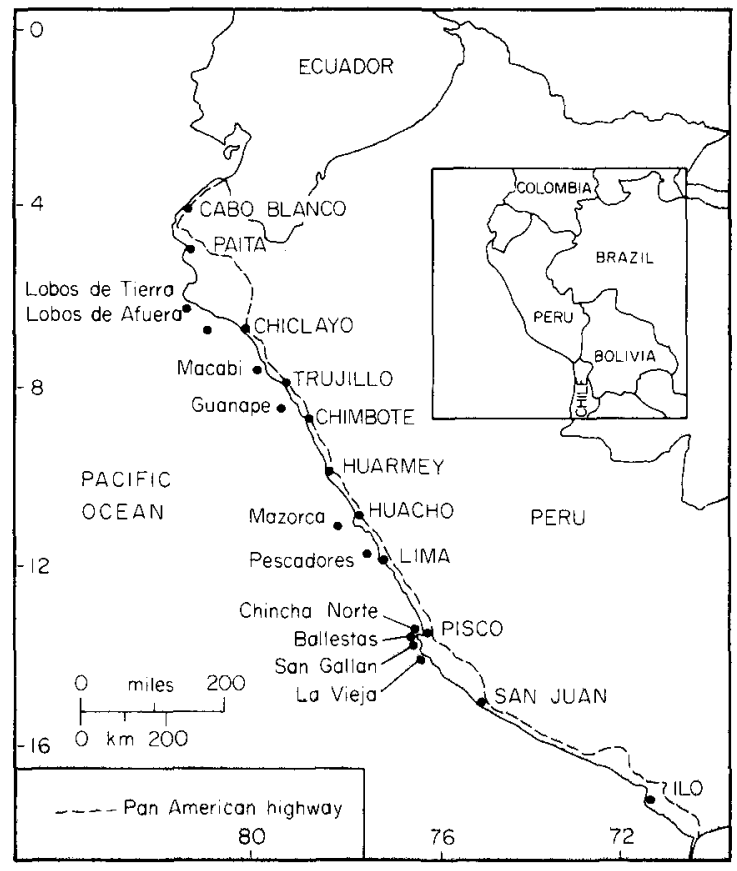

Figure 1. Islands along the coast of Peru where the Peruvlan diving petrel formerly nested.

Oryx Vol 23 No 2, April 1989 
The two major Peruvian breeding sites that are still occupied today are located on San Gallan island $\left(13^{\circ} 50^{\prime} \mathrm{S}\right)$ and La Vieja island $\left(14^{\circ} 17^{\prime} \mathrm{S}\right)$. Both islands are within the boundaries of the National Reserve of Paracas. The breeding timetable of this species is unclear. The most recent reference (Tovar, 1978) reports that they breed from January to March and from September to December. Based on the assumption that there are two breeding seasons, the population was censused during the winter breeding period. The breeding colony at San Gallan was surveyed in October 1985 while La Vieja was surveyed in November 1985.

Descriptions provided by Murphy (1925, 1936) of the previous Peruvian diving petrel colonies on these islands suggest massive decreases in numbers. In order to assess their current status, nests were counted. This species nests in deep burrows excavated in guano, when available, hardened sand, or it may use natural crevices in the salty substrate that is present on the islands. The census of active nest sites was used as an index of the breeding population. Nests were considered active if there were tracks, fresh guano, or fleas at the entrance or in the nesting burrow. On San Gallan, of the 501 nests that were still maintained, 55 per cent (278) were active while 45 per cent (223) were inactive. Applying the ratio of two individuals per active nest gives us a minimum breeding population of 556 individuals. At La Vieja, the minimum breeding population was 1100 individuals. This gives us a total minimum breeding population of 1656 individuals. Under the assumption that there are two distinct populations that breed annually as in Oceanodroma in Galapagos, the population should be doubled. If the estimated winter breeding season consists of 2000 individuals and the summer season consists of a similar number, this gives us a breeding population of 4000 individuals for Peru. The previous estimate of a maximum breeding population of 10,000 individuals (Duffy et al., 1984) may well have been an overestimate.

Records of sightings at sea have also decreased. According to Tovar (1968) large concentrations of Peruvian diving petrels were sighted in the Bay of Independencia during trips at sea in the 1960 s. However, during our recent trip only a solitary individual was seen on the way out to the island of La Vieja and one on the way back. This is another indication that their numbers have greatly diminished in Peru.

\section{Causes of decline}

\section{Guano mining}

Extensive guano mining started in the mid 1800 s. Such activity occurred throughout the year and presumably prevented breeding. Moreover, the nesting substrate of the burrowing species was removed, thus destroying their nesting habitat.

\section{Human exploitation}

During the guano harvest, workers on the islands ate Peruvian diving petrels. Both Coker (1919) and Murphy (1925) state that fishermen and labourers caught them abundantly.

\section{Fishing activities}

Incidental catch of Peruvian diving petrels in purse seine nets during the height of the fish meal industry was apparently quite large although it was never quantified. Fishermen report

Table 1. Islands surveyed by the author where Peruvian diving petrels Pelecanoides garnotti were known to breed formerly

\begin{tabular}{llll}
\hline Site & Date & Breeding evidence & Extent of search \\
\hline Lobos de Tierra & July 1983 & No & Half island, interviewed guard \\
Macabi & April 1984 & No & Thorough \\
Guanape & April 1984 & No & Half island \\
Mazorca & April 1984 & No & Thorough \\
Chincha Norte & March 1984 & No & General, interviewed guard \\
Ballestas & March 1984 & Yes & General, interviewed guard \\
San Gallan & October 1985 & Yes & Very thorough \\
LaVieja & November 1985 & & Very thorough \\
\hline
\end{tabular}

Peruvian diving petrel in Peru 
hundreds of petrels being killed in the nets set for anchovies.

\section{El Niño}

During the 1982-1983 El Niño event, there was a redistribution of the food available to seabirds. This caused increased mortality in the population; petrels were found dead in considerable numbers on beaches throughout the species's range in Peru.

\section{Current threats}

\section{Direct exploitation}

Fishermen and coastal inhabitants still consume Peruvian diving petrels. Local fishermen continue to visit San Gallan to collect these birds, using lanterns to attract the birds at night. During the previous guano harvest on La Vieja, workers dug out petrels from their burrows to eat them (guard, pers. comm.).

\section{Commercial fisheries}

Peruvian diving petrels feed on anchovies Engraulis ringens and silversides Odontesthes regia (Murphy, 1936) in addition to crustaceans and other marine organisms. The anchovy stocks collapsed in the 1970s (Idyll, 1973), and thus there has probably been less food available for this species. Recently, an increase has been noted in the anchovies, but these stocks are being fished, consequently creating a situation of competition with the commercial fisheries. Another potential problem is that the incidental catch in fishing nets is still occurring.

\section{Predators}

Peregrine falcons Falco peregrinus feed on Peruvian diving petrels on both islands. Kelp gulls Larus dominicanus breed in great numbers on the periphery of the petrel breeding colony on La Vieja. Nests of these gulls were lined with petrel skulls and bodies. Turkey vultures Cathartes aura also feed on the petrels (Coker, 1919). Their tracks were common at the entrance of burrows. The Peruvian diving petrel population has been reduced to the point that the total loss to predators is probably substantial in overall population terms.

104

\section{Parasites}

Peruvian diving petrel chicks on San Gallan were found to be infested with fleas. These parasites could possibly transmit disease.

\section{Recommendations}

1. It is imperative that a life-history study of the Peruvian diving petrel be undertaken. In particular, it is necessary to determine the timing and frequency of breeding. The population trend must also be monitored. This would be done most simply by annual counts of occupied burrows in permanently marked areas on both islands. Birds in the study colony should be disturbed as little as possible.

2. In order to ascertain their overall status, it would be crucial to investigate and monitor the species in Chile. Although they have drastically declined in Peru, they may still be numerous in Chile.

3. It is necessary to locate remaining breeding colonies in Peru. The most likely areas are on the mainland of the Paracas National Reserve, across from the breeding islands. This area is remote and isolated.

4. Activities of fishermen on the island of San Gallan should be curtailed. Although this island is within the National Reserve of Paracas, there is currently no control over access to the island.

5. During the guano harvest on La Vieja, the labourers should be prevented from killing petrels. This could be enforced by PESCA-PERU administrators on the island or by the presence of neutral monitors. PESCA-PERU is the entity responsible for the protection and exploitation of the guano islands and promontories. When the timing of breeding is determined then recommendations could be made to PESCA-PERU to conduct the guano harvest outside the species's breeding season.

6. Peruvian diving petrels are not protected by any legislation. They need to be given the status of an endangered species in Peru so that the Oryx Vol 23 No 2, April 1989 
necessary protection can be provided and enforced. In 1919 Coker stated: 'Valued as they are for food and readily open to capture, the potoyunco must eventually be brought near to extinction unless effective efforts for its protection are made.' Sixty-eight years later, we may be very close to facing this reality in Peru.

\section{Acknowledgments}

The field work was supported by a grant from the New York Zoological Society and the International Council for Bird Preservation. I am deeply indebted for the field assistance provided by J. C. Riveros.

\section{References}

Coker, R.C. 1919. Habits and economic relations of the guano birds of Peru. Proc. U.S. Nat. Mus. 56, 449-511.

Duffy, D.C., Hays, C. and Plenge, M. 1984. The conservation status of Peruvian seabirds. ICBP Tech. Pub. No. 2 245-259.

Galarza, N. 1968. Informe sobre estudios ornitologicos realizados en el laboratorio de La Puntilla (Pisco) en setiembre de 1965/66. Inf. Esp. Instit. Mar. Peru-Callao, $31,1-20$.

Idyll, C.P. 1973. The anchovy crisis. Scientific American, 228, 22-29.

Murphy, R.C. 1925. Bird Islands of Peru. Putnams, New York.

Murphy, R.C. 1936. Oceanic Birds of South America. American Museum of Natural History. New York.

Tovar, H. 1968. Areas de reproduccion y distribucion de las aves marinas en el litoral peruano. Bol. Instit. Mar. PeruCallao, 1, 526-545.

Tovar, H. 1978. Avifauna marina en islas del sur peruano. Documenta VI, 64, 40-45.

Coppelia Hays, Royal Society for the Conservation of Nature, PO Box 6354, Amman, Jordan.

Map showing regions used for Briefly...

This map is based on that used by the Widllife Trade Monitoring Unit at the IUCN Conservation Monitoring Centre in Cambridge, UK.

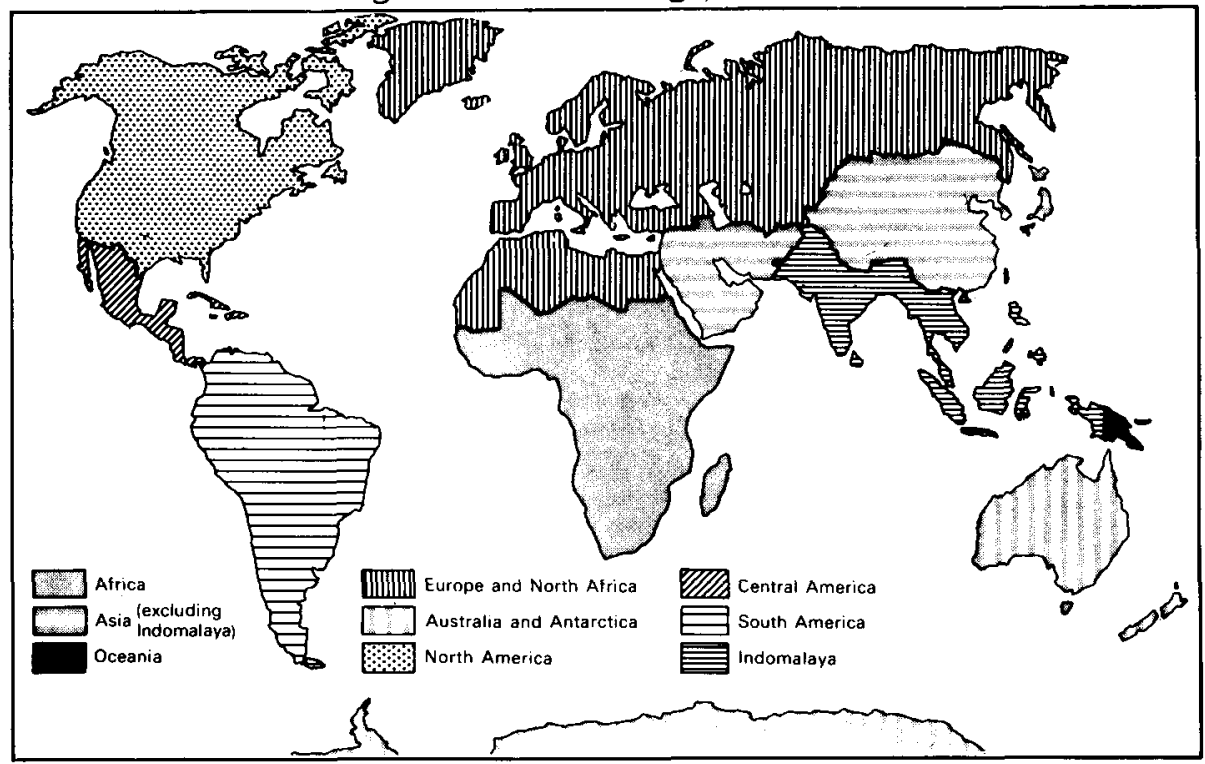

